\title{
Morphophysiological characterization of giant missionary grass accessions $^{1}$
}

\section{Cristiano Reschke Lajús 2,3, Simone Meredith Scheffer-Basso ${ }^{4,5}$, Mario Miranda 3,6 , Rosiane Berenice Nicoloso Denardin ${ }^{2}$, José Francisco Montenegro Valls ${ }^{5,7}$}

\author{
1 Projeto financiado pelo CNPq. \\ 2 Universidade Comunitária da Região de Chapecó (Unochapecó). \\ 3 Programa de Pós-graduação em Agronomia, Universidade de Passo Fundo (UPF). \\ ${ }^{4}$ Universidade de Passo Fundo. \\ 5 Pesquisador CNPq. \\ ${ }^{6}$ Empresa de Pesquisa Agropecuária e Extensão Rural (Epagri). \\ 7 Embrapa Recursos Genéticos e Biotecnologia (Embrapa-Cenargen).
}

\begin{abstract}
In this study, the phenotypic diversity of five accessions of giant missionary grass (Axonopus jesuiticus $\times$ A. scoparius) was evaluated by using morphophysiological traits. Accessions V 14337, V 14403 , V 14404 , V 14405 and V 14406 are hybrids derived from spontaneous crossing that occurred in Vale do Itajaí, Santa Catarina, Brazil. Plants were cultivated in greenhouse and evaluated at 60, 90, 120, 150, 180, 210 and 240 days of growth. Variation was observed for dry matter production, phenology and morphological traits, showing the possibility of selection. Flowering started at 210 days of growth and only in accessions V 14337 and V 14404. The Mahalanobis distance among accessions ranged from 35.64 (V 14403 and V 14405) to 183.38 (V 14337 and V 14405), and three groups were formed, based on 17 vegetative morphophysiological traits evaluated in plants with 180 days of growth: G1 (V 14403, V 14405), G2 (V 14406) and G3 (V 14337, V 14404). Group I presented the greatest dry matter production of stolon and aboveground, which were the traits with the largest relative contribution to genetic divergence, $38.67 \%$ and $38.31 \%$, respectively. Accessions $\mathrm{V} 14403$ and V 14405 are the most promising for agronomic evaluations that address their records as forage cultivars.
\end{abstract}

Key Words: A. catharinensis, dry matter production, growth analysis, phenology

\section{Introduction}

The acquisition, characterization and evaluation of wild germplasm adapted to climate and soil of each region are fundamental for the continuing animal production on pasture, which is the predominant system in Brazil.

In a germplasm collection of forage plants maintained by the Empresa de Pesquisa Agropecuária e Extensão (Epagri), in Vale do Rio Itajaí, Santa Catarina, the introduction of Tcacenco/Ramos 037 (Axonopus spp.) prevailed for its height, productivity and acid soil adaptation (Tcacenco \& Soprano, 1997). The grass is popularly known as missioneiragigante, in this study called giant missionary grass, because of its bigger size in relation to jesuit grass (Axonopus jesuiticus (Araújo) Valls).

The giant missionary grass is a triploid hybrid $(2 n=3 x$ $=30$ ) resulting from natural crossing between $A$. jesuiticus and A. scoparius (Flüggé) Kuhlm., and without viable seeds because the cell meiosis does not produce perfect gametes (Valls et al., 2000). It is a stoloniferous plant, a trait inherited from A. jesuiticus, with branched inflorescence, typical of A. scoparius, and it is vegetatively propagated. It is also referred to as A. catharinensis Valls (Perez, 2008; Probst et al., 2009); however, the publication of this new name is not formalized yet.

Researches have proven the forage potential of this grass related to dry matter production in warm season $(11,700 \mathrm{~kg} \mathrm{DM} / \mathrm{ha})$, and its nutritive value, with levels of up to $11.9 \%$ of crude protein and $70.3 \%$ of in vitro digestibility of organic matter (Tcacenco, 1994; Tcacenco \& Soprano, 1997). Dufloth (2002) stressed its high persistence, animal acceptability and the possibility of ensuring an average daily gain of $0.814 \mathrm{~kg} /$ animal.

The spontaneous hybridization between A. jesuiticus $\times$ A. scoparius occurred in several opportunities, favoring the perpetuation of distinct genotypes (Valls et al., 2000). Epagri added other problable hybrids to its germplasm bank; hybrids whose accessions, analyzed in this study, are available at Embrapa Recursos Genéticos e Biotecnologia, in Brasília, Distrito Federal, Brazil. Limited information regarding the variation that exists in this germplasm is available. 
This study evaluated the divergence between accessions of giant missionary grass, guided by the assumption that there is variability in the germplasm, and that the morphophysiological traits enable its efficient characterization. The information can allow the development of a breeding program by indicating the most promising materials.

\section{Material and Methods}

The research was developed at the research station of Epagri, in Chapecó, Santa Catarina $\left(27^{\circ} 07^{\prime}\right.$ South and $52^{\circ} 37^{\prime}$ West), between August 2008 and April 2009. The climate of the region is Cfa type (Mota et al., 1971) (Figure 1).

Five accessions of giant missionary grass (Table 1 ) were evaluated at 60, 90,120,150, 180, 210 and 240 days of continuous growth, using randomized complete block design, with five replications. Plants were grown in plastic pots filled with $0.5 \mathrm{~kg}$ (60, 90 and 120 days), $2.0 \mathrm{~kg}$ (150 and 180 days) and $4.0 \mathrm{~kg}$ (210 and 240 days) of dried substrate, according to the harvest age. The substrate $\left(\right.$ Ferticel ${ }^{\circledR}$ ) presented the following attributes: $\mathrm{pH}=7.1$; dry matter content $=0.64 \% ; \mathrm{N}=5.72 \mathrm{~g} / \mathrm{kg} ; \mathrm{P}=1.97 \mathrm{~g} / \mathrm{kg} ; \mathrm{K}=2.02 \mathrm{~g} / \mathrm{kg}$; $\mathrm{Ca}=11.01 \mathrm{~g} / \mathrm{kg} ; \mathrm{Mg}=13.12 \mathrm{~g} / \mathrm{kg} ; \mathrm{Cu}=51.46 \mathrm{mg} / \mathrm{kg} ; \mathrm{Zn}=$ $45.80 \mathrm{mg} / \mathrm{kg} ; \mathrm{Fe}=9863.70 \mathrm{mg} / \mathrm{kg}$ and $\mathrm{Mn}=198.35 \mathrm{mg} / \mathrm{kg}$.
Stolon cuttings, presenting one tiller with about $15 \mathrm{~cm}$ of height, two visible nodes, two fully expanded leaves and one expanding leaf, were planted in pots and placed on benches exposed to air under a polyethylene net to avoid rain or hail damages. Plants were watered twice a day, and pots, in each block, were rotated weekly to provide equal light condition to all plants, and minimize variation due to border effects. There was no need for fertilizers or chemical plant protection.

Plants were evaluated according to the following routine: plant height was measured at the highest point, between the ground and the curvature of the upper leaves (vegetative

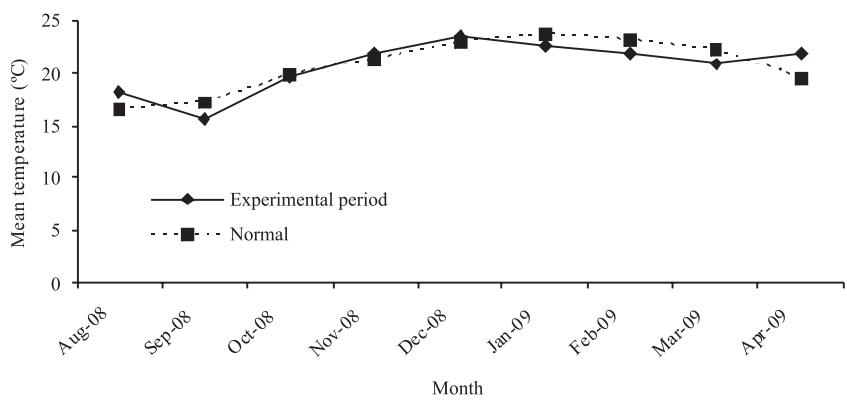

Figure 1 - Mean monthly temperatures during the experimental and normal regional periods(thirty-year mean). Chapecó, Santa Catarina, Brazil.

Table 1 - Identity, denomination and probable origin of giant missionary grass accessions

\begin{tabular}{lccl}
\hline Identity & Accession code & First denomination & \multicolumn{1}{c}{ Origin } \\
\hline V 14337 & Axonopus BRA-002020 & Tcacenco \& Ramos 037 & Originally collected in rural property in Rio do Oeste, \\
& & & SC; kept in cultivation at Epagri, Itajaí, SC, under EEI \\
& & 85269 code; collected for the herbarium, as \\
documental exemplar, in screenhouse at Embrapa & Cenargen, Brasília, DF, under V 14337 code
\end{tabular}

V $14403 \quad$ Axonopus BRA-002429

(missioneira gigante)
Tcacenco \& Ramos 046 (missioneira-pitã-açu)

\footnotetext{
V $14406 \quad$ Axonopus BRA-002453
}

Tcacenco \& Vetterle 048 (missioneira gigante 2)
Originally collected in rural properties in Dona Emma, SC; kept in cultivation at Epagri, Itajaí, SC, under EEI 89028 code; collected for the herbarium, as documental exemplar, in bed cultivation at Epagri, Lages, under VTsRcRMJr 14403 code

Kept in cultivation in the Experimental Station at Epagri, in Lages, SC, coming from Ituporanga, SC, where it was considered as a probable the EEI 85269 accession; collected for the herbarium, as documental exemplar, in bed cultivation at Epagri, Lages, under VTsRcRmJr 14404 code

Originally collected in rural properties in Presidente Getúlio, SC; kept in cultivation at Epagri, Itajaí, SC, under EEI 89009 code; collected for the herbarium, as documental exemplar, in bed cultivation at Epagri, Lages, under VTsRcRmJr 14405 code

Kept in cultivation in the Experimental Station at Epagri, in Itajaí, SC, under a double denomination, EEI 89004 and missioneira roxa Ituporanga at Epagri; collected for the herbarium, as documental exemplar, in bed cultivation at Epagri, Lages, under VTsRcRmJr 14406 code 
height) and tip of inflorescences (reproductive height). The angle of insertion of two peripheral opposite tillers to the ground was determined with a protractor, and after that, plants were removed from the pots. The length of the longest root was measured and the root system volume was determined by the water-level difference, after immersion in a graduated cylinder. The number of tillers was recorded, and in the longest tiller, the diameter of the second basal internode and the number of leaves were estimated. Stolons were counted and their length measured; the longest stolon was evaluated as for diameter of the second internode, counted from the plant insertion, number of nodes and internode average length. Leaf color (green, green-purple) was registered, and the second fully expanded leaf, counted from the tip to the base of the highest tiller, was evaluated as for blade width and its angle of insertion in the tiller. Inflorescences were characterized for length, branch number, length of the longest branch and spikelet number per branch. Roots, green and senesced leaves, stolons, tillers and inflorescences were dried in a forced ventilation oven at $60^{\circ} \mathrm{C}$ during $72 \mathrm{~h}$ and weighed.

Data were submitted to split-plot analysis of variance (main plot: accessions; subplot: days of growth) and regression analysis, using the software package SISVAR (Ferreira, 2000). Means were compared using Tukey's test at the 5\% probability. Genetic divergence was evaluated by multivariate procedures, using 17 vegetative morphophysiological traits recorded in plants with 180 days of growth: Mahalanobis distance, relative importance of characters to genetic divergence, by Singh method (1981), and hierarchical clustering (UPGMA method). Multivariate analysis was performed using the software package Genes (Cruz, 2001).

\section{Results and Discussion}

Aboveground and root dry matter accumulation increased quadratically as function of growing days, with variation between accessions (Figure 2). In plants with 240 days of growth, the dry matter production of these components was 2.0 times greater for V 14403 and V 14405 accessions compared with the other ones. These accessions were also superior as for stolon dry matter accumulation (Figure 3).

In all accessions, the stolon dry matter production was late, only from 120 days, stabilized between 150 and 210 days of growth, followed by resumption of growth rate. The cubical trend observed for this attribute illustrated its rhythmic growth, which is common in stem structures (Barthélémy \& Caraglio, 2007), and suggests a slow establishment of the giant missionary grass. On the other hand, there is reference about its easy establishment and dominance over other species in pastures (Nascimento et al., 1990). This discrepancy is an important aspect to be considered in future field essays because, in this study, stolons went over the edge of the pots and their rooting was restricted. Lateral expansion is one of the most important traits for stoloniferous species, as it implies in soil recovering, competition with other species, efficiency in intercepting radiant energy, and, consequently, faster utilization by animals.

Plants showed significant allocation of dry matter in roots and stolons (Figure 4). Accession V 14337 presented the largest root allocation (43\%), and the opposite was
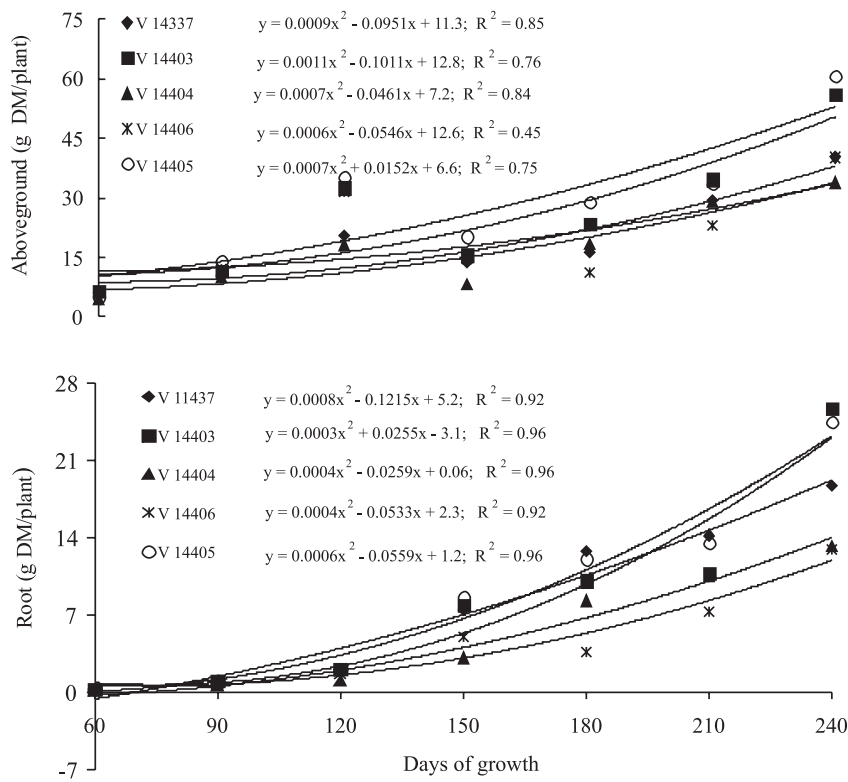

Figure 2 - Aboveground and root dry matter accumulation of giant missionary grass accessions as for days of growth.

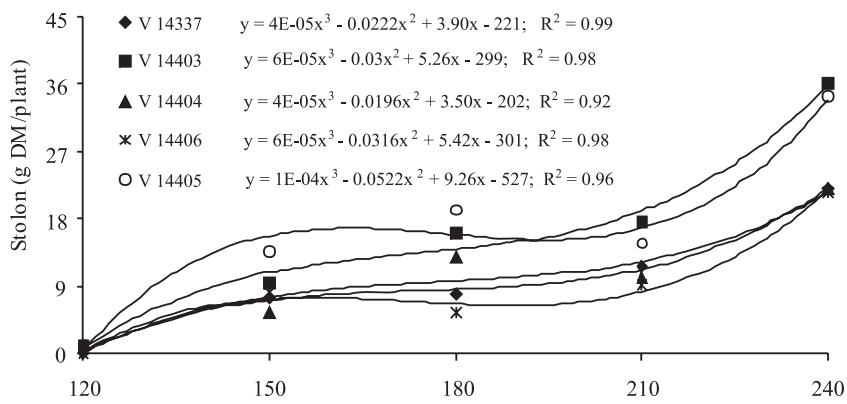

Figure 3 - Stolon dry matter accumulation of giant missionary grass accessions as for days of growth. 
verified in V 14406 (24\%). Nascimento et al. (1990) also reported the high root vigor of V 14337, which, among the hybrids of giant missionary grass, is the most cultivated in Santa Catarina. This feature must be a contributing factor to its high persistence under grazing (Dufloth, 2002) and acid soil tolerance (Tcacenco \& Soprano, 1997).

Tropical grasses, in general, have expressive partitioning in subterranean structures, as it was pointed out by Grise et al. (2006) in cv. Pensacola (Paspalum notatum Flüggé), which allocated between 4 and 12 times more dry matter in roots + rhizomes in relation to aboveground. In the present study, the dry matter partitioning in leaves and tillers was $17 \%$ and $10 \%$ of total dry matter at 240 days of growth, respectively (Figure 4). In aboveground, these components represented $60 \%$ and $40 \%$ of dry matter, respectively, which it is excellent, considering the advanced plant age. This aspect suggests the aptitude of this grass, also, for hay production and deferment.

The relationship between leaf dry matter accumulation and days of growth was linear to accessions V 14337 and V 14403 and quadratic to the other ones (Figure 5). Maximum leaf production was recorded in V 14405 (10 g DM/plant) and the minimum occurred in V 14404 (5.9 g DM/plant), which also presented the smallest leaf senescence (26\%) (Figure 6). In accessions V 14337 and V 14405, senescence reached the highest values, of $39 \%$ and $42 \%$, respectively, suggesting variability in the morphogenesis. Santos (2005)
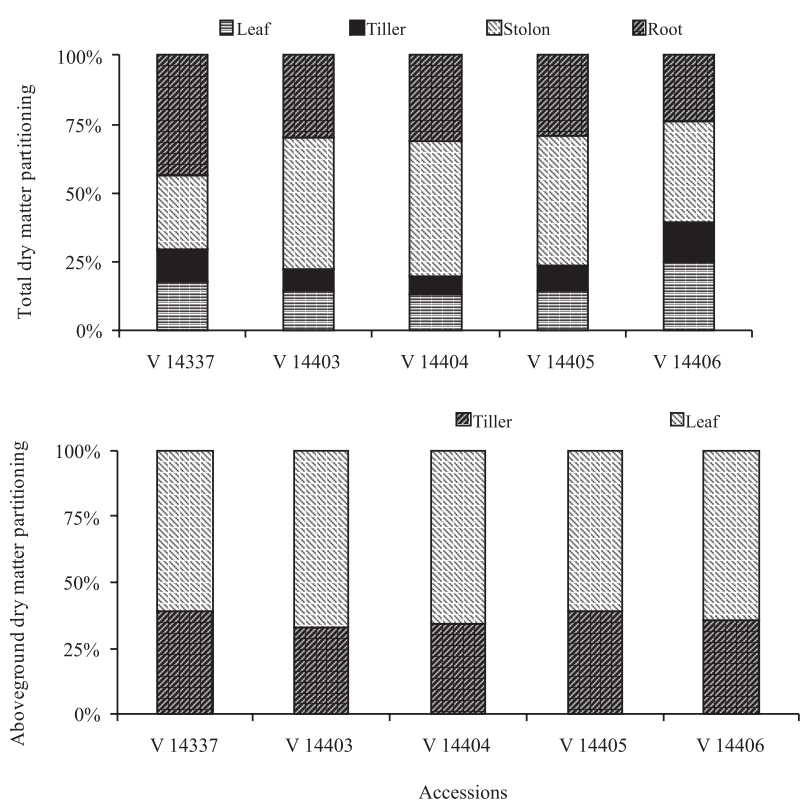

Figure 4 - Partitioning of total (aboveground + roots) and aboveground (leaves + tillers) dry matter of giant missionary grass accessions at 240 days of growth. registered high leaf durability in this grass (accession not mentioned), which was above 1,000 degrees/day (basal temperature $=0^{\circ} \mathrm{C}$ ).

Accessions varied in relation to phenology, since flowering was only observed in accessions V 14337 and V 14404, from 210 days of growth. These materials exhibited differences as for reproductive canopy height and inflorescence morphological traits (Table 2), except for inflorescence dry matter production, which was negligible. However, through cluster analysis, which considered only the vegetative characters, these materials remained in the same group (Figure 7). In the dendrogram generated by

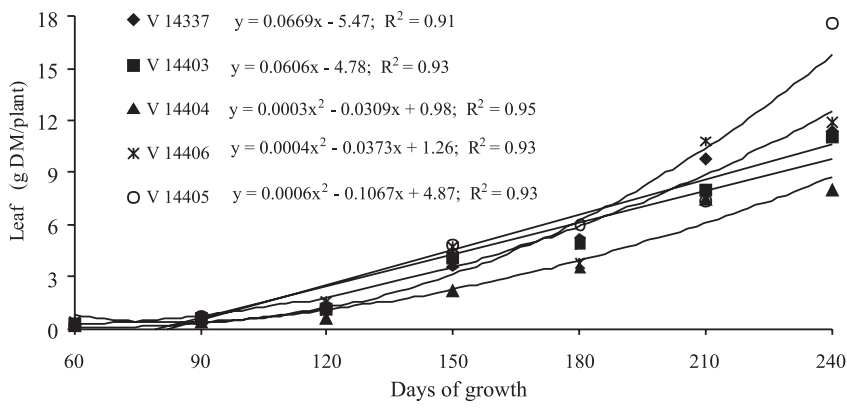

Figure 5 - Leaf dry matter accumulation of giant missionary grass accessions as for days of growth.

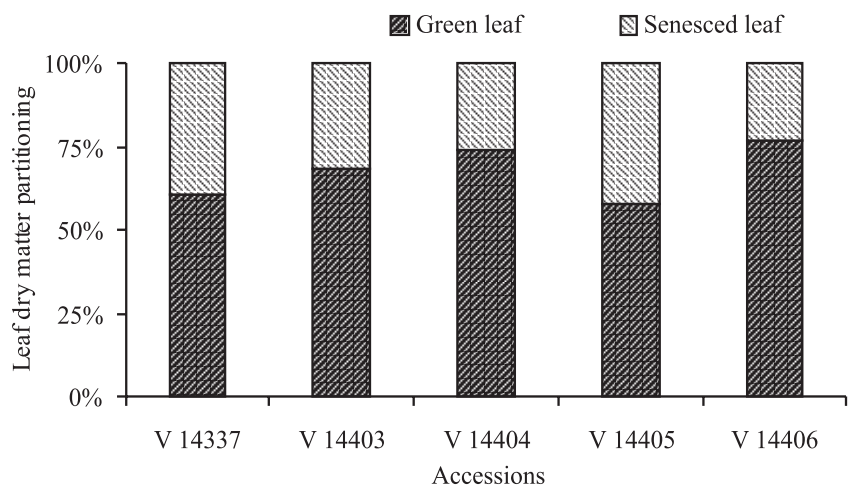

Figure 6 - Leaf dry matter partitioning of giant missionary grass accessions at 240 days of growth.

Table 2 - Reproductive morphophysiological traits of two giant missionary grass accessions

\begin{tabular}{lrc}
\hline Traits & $\mathrm{V} 14337$ & $\mathrm{~V} 14404$ \\
\hline Reproductive canopy height $(\mathrm{cm})$ & $76.28 \mathrm{a}$ & $42.85 \mathrm{~b}$ \\
Reproductive tiller length $(\mathrm{cm})$ & $74.28 \mathrm{a}$ & $17.14 \mathrm{~b}$ \\
Branch number/inflorescence & $13.42 \mathrm{a}$ & $2.85 \mathrm{~b}$ \\
Longest branch length (cm) & $9.71 \mathrm{a}$ & $3.14 \mathrm{~b}$ \\
Spikelet number/longest branch & $24.57 \mathrm{a}$ & $7.71 \mathrm{~b}$ \\
Inflorescence dry matter production & $0.15 \mathrm{a}$ & $0.05 \mathrm{a}$ \\
(g DM/plant) & & \\
\hline
\end{tabular}

Means followed by same letter in the row do not differ $(\mathrm{P}>0.05)$ by Tukey test. 
UPGMA method, assuming 50\% of relative distance among accessions, three groups were formed: group I: V 14403 and V $14405\left(D^{2}=35.64\right)$, group II: V 14406 and group III: $\mathrm{V} 14337$ and V $14404\left(\mathrm{D}^{2}=56.36\right)$. The greatest divergence was verified between $V 14337$ and $V 14405\left(D^{2}=183.38\right)$.

Considering the traits with the highest relative contribution for genetic divergence (Table 3), stolon and aboveground dry matter production, the clustering was very consistent and expressed the accession yield performance. Group I was the most productive, and the opposite characterized the group II (Figure 8). The only accession that formed group II, V 14406, stood out from the others by its upright growth habit, demonstrated by greater angle of tiller insertion with the ground (Table 4), as well as by color leaf, which is green-purple. These attributes are characteristic of A. scoparius (Lima et al., 2001; GiraldoCañas, 2008), one progenitor of this hybrid.
Table 3 - Relative contribution for the genetic divergence (R.C.G.D), by Singh method (1981), of vegetative morphophysiological traits evaluated in giant missionary grass accessions at 180 days of growth

\begin{tabular}{lc}
\hline Traits & R.C.G.D (\%) \\
\hline Green leaf dry matter production (g/plant) & 5.76 \\
Senesced leaf dry matter production (g/plant) & 1.10 \\
Tiller dry matter production (g/plant) & 1.78 \\
Stolon dry matter production (g/plant) & 38.67 \\
Aboveground dry matter production (g/plant) & 38.31 \\
Root dry matter production (g/plant) & 0.044 \\
Total dry matter production (aboveground + & 6.08 \\
root; g/plant) & \\
Stolon (n $/$ plant) & 0.16 \\
Diameter of the longest stolon (mm) & 1.37 \\
Length of the longest stolon (cm) & 0.66 \\
Node (n $\%$ longest stolon) & 0.53 \\
Internode of the longest stolon (cm) & 0.22 \\
Vegetative canopy height (cm) & 0.35 \\
Tiller (n ${ }^{\circ}$ plant) & 1.10 \\
Leaf (n ${ }^{\%}$ plant) & 2.26 \\
Leaf blade width (cm) & 0.25 \\
Leaf blade length (cm) & 0.17 \\
\hline
\end{tabular}

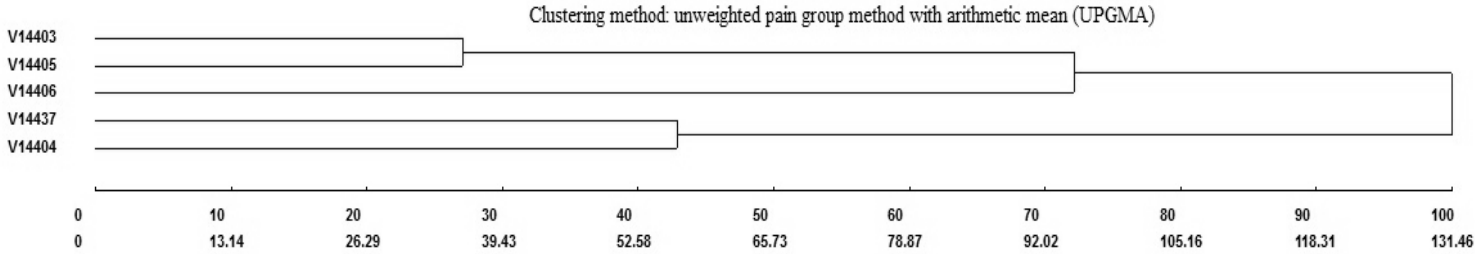

Figure 7 - Dissimilarity dendrogram of five giant missionary grass accessions obtained by UPGMA method, based on Mahalanobis distance, using 17 vegetative morphophysiological traits evaluated in plants with 180 days of growth. Cutting point $=50 \%$ of relative distance.

Table 4 - Vegetative morphophysiological traits of giant missionary grass accessions, at 180 days of growth

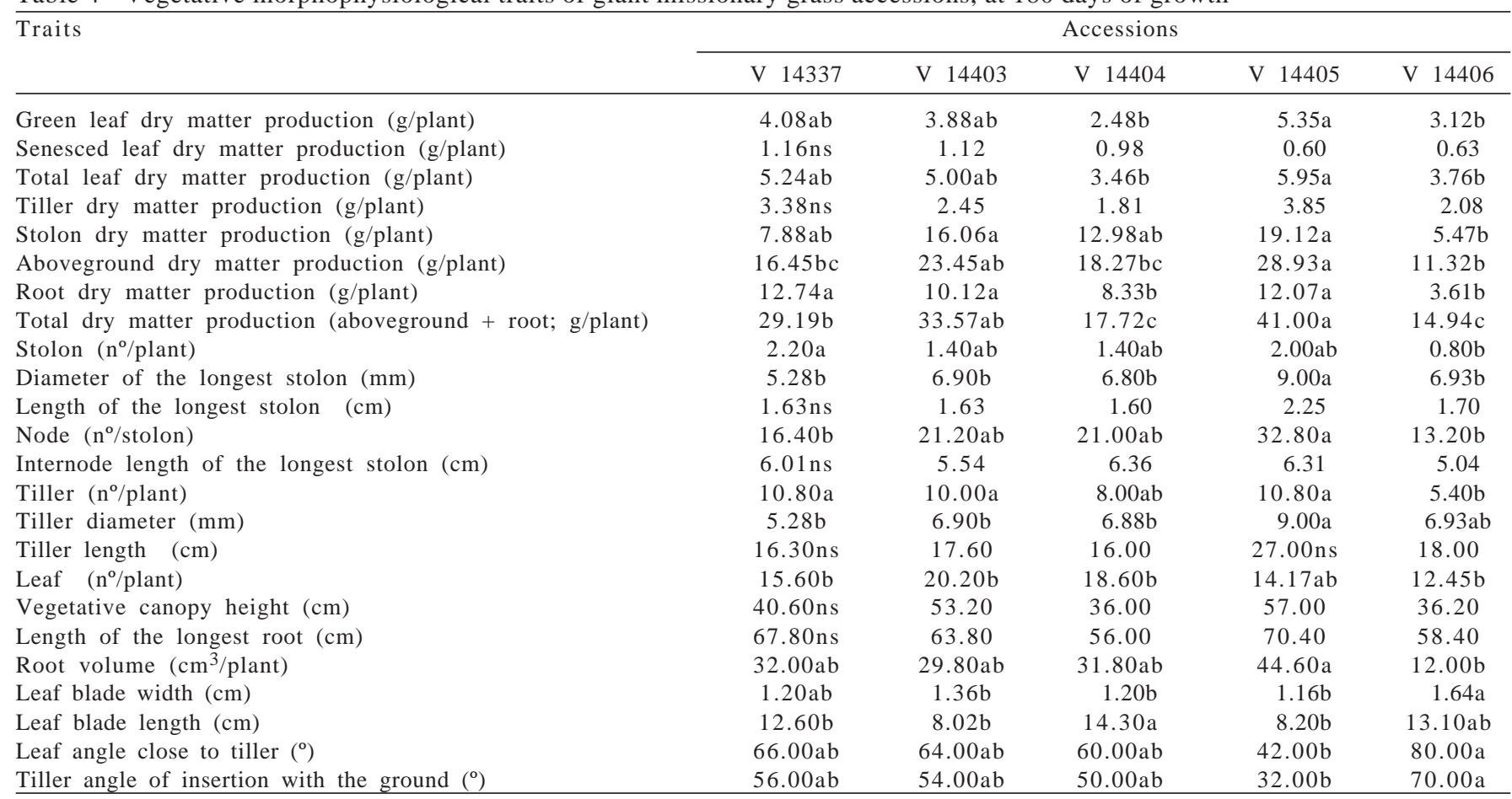

Means followed by the same letter in the row do not differ $(\mathrm{P}>0.05)$ by Tukey test; ns $=$ not significant. 


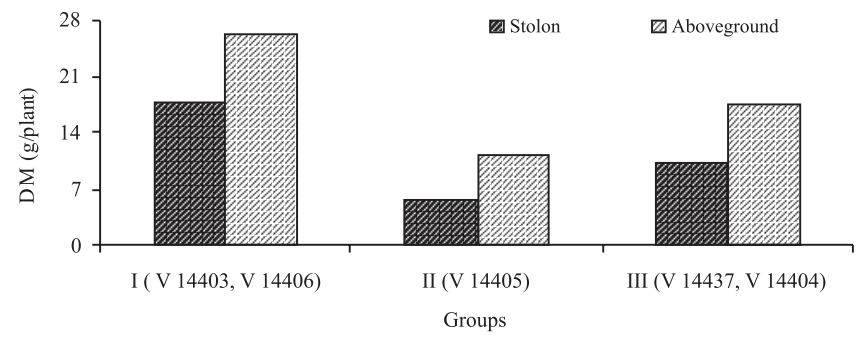

Figure 8 - Average dry matter production of aboveground and stolon of the groups formed by UPGMA method, based on Mahalanobis distance among accessions of giant missionary grass.

The morphophysiological traits used to characterize the giant missionary grass accessions showed that there is variability in the germplasm (Table 4), which credits its evaluation in field experiments, to describe the variation for attributes of agronomic importance (Jaramillo \& Baena, 2000). The new information about the accessions can contribute to their conservation, use and management, offering subsides to the species breeding program.

\section{Conclusions}

Morphophysiological traits are efficient to evaluate the variability in the giant missionary grass accessions, which vary as for growth habit, morphology, dry matter accumulation and phenology. Accessions V 14337 and V 14404 are earlier for flowering, and V 14403 and V 14405 are the most promising to further agronomic evaluation aiming at cultivar registration.

\section{References}

BARTHÉLÉMY, D.; CARAGLIO, Y. Plant architecture: a dynamic, multilevel and comprehensive approach to plant form, structure and ontogeny. Annals of Botany, v.99, p.375-407, 2007.

CRUZ, C.D. Programa Genes Versão Windows: Aplicativo computacional em genética e estatística. Viçosa, MG: Editora UFV, 2001. 648p.

DUFLOTH, J.H. Missioneira gigante: uma nova opção na produção do novilho precoce. Agropecuária Catarinense, v.15, n.2, p.23, 2002.
FERREIRA, D.F. Sistema de análises de variâncias para dados balanceados - SISVAR 4.1. Lavras: Editora UFLA, 2000. 141p. GIRALDO-CAÑAS, D. Revisión del género Axonopus (Poaceae: Paniceae): primer registro del género en Europa y novedades taxonómicas. Caldasia, v.30, n.2, p.301-314, 2008.

GRISE, M.M.; SOLLENBERGER, L.; DUBEUX, J.R. et al. Partição da biomassa e qualidade da forragem de Bahiagrass; Paspalum notatum cv. Pensacola no centro-norte da Flórida. Acta Scientarum Animal Science, v.28, n.4, p.375-383, 2006.

JARAMILLO, S.; BAENA, M. [2000]. Material de apoyo a la capacitación en conservación ex situ de recursos fitogenéticos. IPGRI, Cali, Colômbia, 209p. Available at: $<$ http://www.ipgri.cgiar.org> Accessed on: Jun. 5, 2011.

LIMA, L.M.S.; ALQUINI, Y.; BRITO, C.J.F.A. et al. Área de tecidos de folhas e caules de Axonopus scoparius (Flügge) Kuhlm. e Axonopus fissifolius (Raddi) Kuhlm. Ciência Rural, v.31, n.3, p.425-430, 2001.

MOTA, F.S.; BEIRSDORF, F.; GARCEZ, J.R.B. Zoneamento agroclimático do Rio Grande do Sul e Santa Catarina - Normais agroclimáticas. Pelotas: Ministério da Agricultura, 1971. 80p.

NASCIMENTO, J.A.L.; FREITAS, E.A.G.; DUARTE, C.M.L. A grama missioneira no Planalto Catarinense: produção de forragem, valor nutritivo e ganho de peso nas condições de manejo do produtor. Florianópolis: Empasc, 1990. 65p (Boletim Técnico, 52).

PEREZ, N.B. [2008]. Multiplicação vegetativa de plantas forrageiras: recomendações para plantio. Bagé: Embrapa Pecuária Sul, 2008. (Documentos/Embrapa Pecuária Sul, 73). Available at: <http://www.cppsul.embrapa.br/unidade/publicacoes> Accessed on: Dec. 21, 2010.

PROBST, R.; QUADROS, S.A.F.; ERPEN, J.G. et al. Produção de mudas de espécies forrageiras no sistema hidropônico de leito flutuante (floating) com solução nutritiva à base de biofertilizante ou adubo solúvel. Acta Scientiarum, v.31, n.4 p.349-355, 2009.

SANTOS, R.J. Dinâmica de crescimento e produção de cinco gramíneas nativas do sul do Brasil. 2005. 110f. Dissertação (Mestrado em Zootecnia) - Faculdade de Agronomia/Universidade Federal do Rio Grande do Sul, Porto Alegre.

SINGH, J. The relative importance of characters affecting genetic divergence. The Indian Journal of Genetic and Plant Breeding, v.41, n.2, p.237-245, 1981.

TCACENCO, F.A. Avaliação de forrageiras nativas e naturalizadas, no Vale do Itajaí, Santa Catarina. Pesquisa Agropecuária Brasileira, v.29, n.3, p.475-489, 1994.

TCACENCO, F.A.; SOPRANO, E. Produtividade e qualidade da grama missioneira [Axonopus jesuiticus (Araújo) Valls] submetida a vários intervalos de corte. Pasturas tropicales, v.19, n.3, p.28-35, 1997.

VALLS, J.F.M.; SANTOS, S.; TCACENCO, F.A. et al. A grama missioneira gigante: híbrido entre duas forrageiras cultivadas do gênero Axonopus (Gramineae). In: CONGRESSO NACIONAL DE GENÉtiCA, 46., 2000, Águas de Lindóia. Anais... Águas de Lindóia: Sociedade Brasileira de Genética, [2000]. (CD-ROM). 